DOI: https://doi.org/10.32353/khrife.1.2021.28

UDC 343.98

\title{
O. Manulenko,
}

Senior Researcher of the Laboratory of Forensic Economic, Commodity Expertise, Forensic Psychology and Intellectual Property Analyses at NSC «Hon. Prof. M. S. Bokarius FSI», Kharkiv, Ukraine, ORCID: https://orcid.org/0000-0001-7954-1261, e-mail: maleksaa@ukr.net

\section{T. Zanina,}

Senior Researcher of the Laboratory of Forensic Economic, Commodity Expertise, Forensic Psychology and Intellectual Property Analyses at NSC «Hon. Prof. M. S. Bokarius FSI», Kharkiv, Ukraine, ORCID: https://orcid.org/0000-0002-2476-860X, e-mail: tanyazan_@ukr.net

\section{A. Kopytko,}

Senior Researcher of the Laboratory of Forensic Economic, Commodity Expertise, Forensic Psychology and Intellectual Property Analyses at NSC «Hon. Prof. M. S. Bokarius FSI», Kharkiv, Ukraine,

ORCID: https://orcid.org/0000-0002-8852-1024, e-mail: k_oalla@ukr.net

\section{T. Cechin,}

Third Category Judicial Expert of the Laboratory of Economic Judicial Expertise, National Center for Forensic Expertise of the Ministry of Justice of the Republic of Moldova, Chișinău, Republic of Moldova

\section{Problematic issues on the evaluation of domestic animals during forensic commodity expertises}

The article purpose is to address problematic issues during forensic commodity expertises on the evaluation of pets, in particular, to determine the material damage caused to an animal owner, in case of animal abuse and injuries, mutilation or death of an animal. The animal in this case is the object of civil relations.

Carrying out forensic commodity expertises on evaluation of pets, in particular, to determine the material damage caused to an animal owner in case of animal abuse, requires an individual approach in each case, taking into account individual characteristics and obtaining complete initial data to identify objects of study.

Keywords: forensic commodity expertise, evaluation, market price, domestic animals, financial loss, cruelty to animal.

Formulation of Research Problem. The development of society is characterized by a strategic course to create the rule of law, public consciousness and tolerance. Decent treatment of animals is an important component of modern society. 
Recently, shocking photos and videos about cruelty to animals have become more common on the Internet. At the legislative level, it is very difficult to prove the guilt of a person in the case of cruelty to animals and to bring him to justice with compensation for financial loss caused to the animal owner.

At NSC «Hon. Prof. M. S. Bokarius FSI» the number of expertises related to evaluation of pets has been significantly increased.

Since the problem of evaluating a farm animal in commodity science has been fully disclosed, this article discusses the problem of evaluating another category of pets, namely companion animals and ornamental pets (in order to determine the market price of animals and financial loss to animal owners in case of cruelty to animals with bodily injuries, mutilation or death of an animal).

Analysis of Essential Researches and Publications. Peculiarities of this problem have been studied by such scientists as D. O. Kalmykov, A. O. Danylevskyi, I. V. Yatsenko, L. M. Derecha, O. I. Parylovskyi, D. O. Antoniuk, V. O. Turska, A. A. Marchuk, O. V. Shevchenko, I. A. Holovko, S. I. Zapara, A. V. Zakhariev, M. V. Skrypka, Ya. K. Serdiukov and others. ${ }^{1}$

The Article Purpose is to is to address problematic issues during forensic commodity expertises on the evaluation of domestic animals (in particular, to determine the financial loss caused to an animal owner, in case of cruelty to animals and causing injuries, mutilation or death of an animal).

Main Content Presentation. In discipline: Commodity Science there are no sections of product groups, which would indicate such goods as companion

${ }^{1}$ Е.g., Яценко І. В., Дереча Л. М., Париловський О. І. Особливості структури висновку судово-ветеринарного експерта за результатами дослідження трупа тварини з ознаками насильницької смерті. Теорія та практика судової експертизи і криміналістики : зб. наук. пр. Харків, 2020. Вип. 21. С. 615-639. DOI: https://doi.org/10.32353/ khnrife.1.2020.44 (date accessed: 18.03.2021); Турська В. О. Адміністративно-правове регулювання захисту тварин від жорстокого поводження : дис. ... канд. юрид. наук. Одеса, 2016. 232 с. ; Калмиков Д. О., Данилевський А. О. Кримінальна та адміністративна відповідальність за жорстоке поводження з тваринами : монографія. Луганськ, 2013. 615 с. ; Антонюк Д. О. Жорстоке поводження з тваринами: поняття та ознаки складу злочину. Четверті харківські кримінально-правові читання : тези доп. та наук, повідомл. учасн. Міжнар. наук. конф. студ. та аспірантів (Харків, 16-17.05.2014). Харків, 2014. С. 373-376 ; Марчук А. А. Особливості експертної оцінки вартості домашніх тварин. Науково-технічний бюлетень Інституту тваринництва НААН. 2020. № 123. C. 104-117. URL: https://animal.kharkov.ua/ archiv/ntb/STB123/15.pdf (date accessed: 12.03.2021) ; Шевченко О. В. Використання спеціальних товарознавчих знань під час досудового розслідування : дис. ... канд. юрид. наук. Київ, 2017. 317 с. ; Головко І. А. Кримінальна відповідальність за жорстоке поводження з тваринами : автореф. дис. ... канд. юрид. наук. Київ, 2010. 23 с. ; Яценко I. В., Запара С. І., Захар'єв А. В., Кириченко В. М., Скрипка М. В., Сердюков Я. К. Судово-експертні випадки дослідження трупів тварин з ознаками насильницької смерті від жорстокого поводження. Проблеми зооінженерії та ветеринарної медицини : зб. наук. пр. ХДЗВА. Харків, 2018. Вип. 35. Ч. 2. Т. 3. C. $130-138$. 
animals and ornamental pets, but with the development of the market and market relations, these goods are gaining momentum in the Ukrainian market and become objects of forensic commodity expertises and expert researches. Increasingly, forensic investigative bodies, other organizations and citizens turn to expert institutions with questions regarding the valuation of companion animals, ornamental animals, which are sold on the market of Ukraine at market prices and are subject to commodity evaluation. Taking into account the aforementioned and the practical experience of commodity experts of forensic expert institutions of the Ministry of Justice of Ukraine, which conducted examinations on evaluation of domestic animals, in particular, to determine the financial loss caused to the animal owner, developed an algorithm to address this problematic issue.

After the adoption of the Law of Ukraine: On Protection of Animals from Cruelty in 2006, a system of legal norms appeared in the field of regulation of keeping animals in Ukraine, protection of them from cruel treatment. Prior to the adoption of this Law, these issues were not regulated at the legislative level, except for the rules on criminal and administrative liability for cruelty to animals. However, despite the huge number of cases of cruelty to animals in Ukraine, which caused both by individuals and local governments, most offenses remain unpunished.

In Article 1 of the Law of Ukraine: On Protection of Animals from Cruelty ${ }^{1}$ the following terms and concepts used in this research paper are provided:

- animals - biological objects related to fauna: domestic, pets, wild, including poultry and wild birds, fur, laboratory, zoo, circus;

$<\ldots>$

- domestic animals - dogs, cats and other animals traditionally kept and bred by man for a long historical period, as well as animals of species or breeds artificially bred by man to meet aesthetic and communication needs, which generally do not have viable wild populations from individuals with similar morphological features and exist for a long time in their natural range;

$<\ldots>$

- cruelty to animals - abuse of animals, including stray ones, which caused torture, physical suffering, bodily injuries, mutilation or death, inciting animals against each other and other animals committed for hooligan or selfish motives, leaving domestic and farm animals to the mercy of fate, including violation of the rules of keeping animals ${ }^{2}$.

In Ukraine, the legislation provides both administrative and criminal responsibility for cruel treatment of animals. These types of responsibility differ in the severity of consequences, they are considered in different court proceedings.

1 Про захист тварин від жорстокого поводження : Закон України від 21.02.2006 p. № 3447-IV (as amended and supplemented). URL: https://zakon.rada.gov. ua/laws/show/3447-15 (date accessed: 15.03.2021).

${ }^{2}$ Ibidem. 
Article 299 part 1 of the Criminal Code of Ukraine ${ }^{1}$ states:

Cruel treatment of vertebrate animals, including stray animals, which is committed intentionally and resulted in mutilation or death of an animal, as well as inciting animals against each other or other animals, committed for hooligan or selfish motives, public appeals to commit acts that show signs of cruelty to animals, as well as the dissemination of materials calling for such actions are punishable by a fine of one thousand to three thousand non-taxable minimum incomes or arrest for a term up to six months or restriction of liberty for a term up to three years ${ }^{2}$.

Article 89 part 1 of the Code on Administrative Offense ${ }^{3}$ states:

Cruelty to vertebrate animals: abuse of animals, beatings or other acts of violence that caused the animal physical pain, suffering and did not cause bodily harm, mutilation or death, abandonment of animals, including violations of the rules of keeping animals, entail imposition of a fine of two hundred to three hundred non-taxable minimum incomes of citizens with confiscation of an animal, if the stay of the animal with the owner poses a threat to its life or health ${ }^{4}$.

In accordance with the Article 180 parts 1 and 2 of the Civil Code of Ukraine (hereinafter referred as $\mathrm{CCU})^{5}$ :

1. Animals are a special object of civil rights. They are subject to the legal regime of the thing, except in cases established by law.

2. Rules for the treatment of animals shall be established by law ${ }^{6}$.

The norm of this Article does not limit the range of animals that may be objects of civil law. Such objects can be farm, domestic and other animals, which are used for economic, scientific, educational, cultural and educational, aesthetic and other needs. The Civil Code of Ukraine expands the legal regulation of relations, the object of which are animals. This need is due to the increase in related offenses and the need to protect them from cruel treatment. This Article contains two norms aimed at achieving the mentioned goal. The first norm applies to animals general rules of ownership unless otherwise provided by law or other legal acts. The second one defines the limits of the exercise of rights to which they are subject: the prohibition of cruel treatment.

${ }^{1}$ Кримінальний кодекс України : Закон України від 05.04.2001 p. № 2341-III (as amended and supplemented). URL: https://zakon.rada.gov.ua/laws/show/2341-14 (date accessed: 18.03.2021).

${ }^{2}$ Ibidem.

${ }^{3}$ Кодекс України про адміністративні правопорушення : Закон України від 07.12.1984 p. № 8073-X (as amended and supplemented). URL: https://zakon.rada.gov. ua/laws/show/80731-10 (date accessed: 18.03.2021).

${ }^{4}$ Ibidem.

${ }^{5}$ Цивільний кодекс України : Закон України від 16.01.2003 р. № 435-IV (зі змін. та допов.). URL: https://zakon.rada.gov.ua/laws/show/435-15 (date accessed: 18.03.2021).

${ }^{6}$ Ibidem. 
Thus, according to the Article 180 part 2 of the $\mathrm{CCU}^{1}$, non-compliance with this prohibition should be considered an abuse of rights. In cases of cruelty to animals, the termination of ownership is carried out in court. Damages caused to animal owners are subject to compensation in the manner prescribed by law. Belonging of live animals to the category of object of civil rights is due to the fact that the latter are the objects of evaluation in material form: movable property, consumer goods. Thus, the assessment turns the animal into a special object of civil rights, which is covered by the legal regime of the thing.

Assessment of losses incurred by an animal owner and their compensation is regulated by Art. 22 of the Civil Code of Ukraine Compensation for Damages and Other Methods of Compensation for Property Damage ${ }^{2}$.

If an animal is injured or killed through the fault of an individual (including traffic accidents) or an organization (for example, a public service dealing with animals killing), the animal owner may order a commodity expertise to evaluate the damage.

Financial loss — property loss: reduction of the value of the damaged thing, reduction or loss of income, the need for new expenses, etc. It can be reimbursed in kind or in cash. In the cases, considered in this article, monetary compensation of the caused damage, i.e. compensation of losses is more often used.

Compensation for damages is a measure of civil liability determined by law. The losses in civil law are understood as the monetary valuation of property losses (damages). They contain:

- firstly, the costs incurred or to be incurred by the victim to remedy the consequences of the offense;

- secondly, the value of the lost or damaged property of the victim;

- thirdly, the income not received by the victim, which he could receive in the absence of the offense (Article 15 part 2 of the CCU) ${ }^{3}$.

The costs of the victim and damage to his property are covered by the concept of real damage, i.e. money damage.

The victim must convincingly prove in court the fact of financial loss, as well as his unconditional rightness in calculating the amount of damage.

Confirmation of the amount of real losses are: a documentary proof of the price of damaged or lost property, the documentary proof of the price of an analogue of tangible properties, a conclusion of the expertise on the price of the subject of the dispute, etc.

All calculations are made in advance and added in the form of separate documents to the statement of claim.

\footnotetext{
${ }^{1}$ Цивільний кодекс України ... . URL: https://zakon.rada.gov.ua/laws/show/435-15 (date accessed: 18.03.2021).

${ }^{2}$ Ibidem.

${ }^{3}$ Ibidem.
} 
To compensate for losses, associated with the death or harm to the animal, people order a commodity expertise. Most often, the assessment is performed if the animal was injured (or died) due to:

- illegal, hooligan actions (for example, abuse of an animal, intentional infliction of bodily harm, poisoning, that caused mutilation or death of the animal);

- careless actions of third parties, traffic accidents (for example, a pet jumped on the road and fell under the wheels of a car);

- actions of a specialized service engaged in catching stray animals;

- violations of transportation rules (for example, when transporting animals from one farm to another, the weather conditions were not taken into account, due to which the animals became frostbitten and became ill);

- the insured event (for example, a snake bite, falling from a height, as well as some similar situations due to the relevant contract);

- an emergency or natural disaster (for example, fire, flood, hurricane, storm, blizzard, hail, etc.); • forced slaughter due to the threat of infection (for example, slaughter of birds during an epidemic of the bird flu).

Depending on the specific evaluating situation, the performing of the commodity expertise makes it possible to obtain compensation from a perpetrator, from the state or local authorities, from the insurance company. An expert conclusion, based on the results of forensic commodity expertise, is one of the evidences, provided by the Procedural Codes of Ukraine, the Law of Ukraine On Forensic Examination and the Instruction on the appointment and conduct of forensic examinations and expert researches ${ }^{1}$.

The problem is that during this type of research it is required a complete list of initial data about the object of research, a set of morphological, physiological (external, internal) indicators, economic characteristics, and properties that form and characterize the animal as a whole. Each indicator and feature affect this value.

In everyday life, a person keeping a domestic animal does not pay attention to certain details that are extremely important during the evaluation, and sometimes the lack of information from the owner of the object of research leads to the impossibility of resolving the issue before the forensic expert ${ }^{2}$.

${ }^{1}$ Про судову експертизу : Закон України від 25.02.1994 р. № 4038-XII (as amended and supplemented). URL: https://zakon.rada.gov.ua/laws/show/4038-12 (date accessed: 18.03.2021) ; Інструкція про призначення та проведення судових експертиз та експертних досліджень : затв. наказом Мін’юсту України від 08.10.1998 р. № 53/5 (as amended and supplemented.) URL: https://zakon.rada.gov.ua/laws/show/z0705-98 (date accessed: 18.03.2021).

${ }^{2}$ Марчук А. A. Op. cit. URL: https://animal.kharkov.ua/archiv/ntb/STB123/15.pdf (date accessed: 12.03.2021). 
To address the issue of determining the value of financial loss caused to the owner of the animal, the research must provide the following documents:

- information about the customer (passport data or company details: for the execution of contract);

- documents confirming property rights in relation to animals;

- evidences of harm or death of the animal (photos and videos, expert conclusions, acts signed by the police, vet, traffic police officers, representatives of the insurance company, meteorological center certificates, etc.);

- veterinary documents (official consent documents, which include: international veterinary certificate, veterinary card, license and certificate, as well as veterinary passport for the animal issued by state veterinary inspectors or authorized or licensed veterinarians, who confirm the animal's veterinary status);

- pedigree and information about previous generations;

- work certificates, diplomas, documents on titles obtained at exhibitions, etc., received by the pet;

- for legal entities: accounting documents, initial and residual book value, profit and loss report.

- documents confirming the costs of maintenance, training, treatment of the pet (checks from the veterinary clinic, pet store, contract with the club, recorded evidence of the breeder, etc.).

Having considered the set of indicators that form and characterize the animal as a whole when determining its value in the case of commodity research, let us turn to the analysis of the specificity of practical experience in determining the value of domestic animals (domestic animals are cats, dogs and other animals that have long been bred and held by people; this also includes animals of species or breeds, artificially bred by humans to meet aesthetic needs, which usually do not have viable wild populations), for example, determining the value of dogs during the commodity expertise ${ }^{1}$.

Companion animals, as well as pets, is a term used to denote domestic animals that a person keeps in their home to communicate and receive positive emotions. These domestic animals are opposed to farm ones, which are kept as working cattle, as well as for meat and dairy products, wool, etc. the most common and traditional companion animals are dogs and cats.

The evaluation of domestic animals, in particular, in order to determine the financial loss caused to the animal owner is determined, taking into account the basic principles set out in the National Standard № 1: General Principles of Property Valuation and Property Rights ${ }^{2}$ :

${ }^{1}$ Марчук A. A. Op. cit. URL: https://animal.kharkov.ua/archiv/ntb/STB123/15.pdf (date accessed: 12.03.2021).

2 Про затвердження Національного стандарту № 1 «Загальні засади оцінки майна і майнових прав» : Постанова КМУ від 10.09.2003 p. № 1440 (as amended and supplemented). URL: https://zakon.rada.gov.ua/laws/show/1440-2003-п (date accessed: 12.03.2021). 
6. The principle of supply and demand reflects the correlation between demand and supply for such property. In accordance with this principle, while evaluating the market fluctuations in prices for similar property and other factors are taken into accounts that may lead to changes in the correlation between demand and supply for such property.

7. The principle of substitution provides $\langle\ldots\rangle$, that an amount greater than the minimum price of property of the same utility sold at the market is not paid property acquisition ${ }^{1}$.

Let us consider the determination of the value of pets, in particular, in order to determine the financial loss caused to the animal owner, using an example of evaluating dogs during the commodity expertise.

For the research it is necessary to get complete information about the object of research, provide all initial data, breed standard (within the breed: traits), age, sex, health status, body composition, height, weight, ability to reproduce, pedigree, movements, wool, behavior, defects (any deviation from the above categories should be considered as a defect depending on the severity), the dog's achievement of certain physiological parameters (weight, height), mastery of certain skills and suitability to perform the work. It is also needed to obtain the appropriate form of breeding documentation: a certificate, information about the origin of the animal, passport or registration certificate (puppy metrics), a copy of the passport indicating vaccinations (veterinary card), information (confirmed by relevant documents) on all costs of the object $(\operatorname{dog})^{2}$ :

- purchase of a puppy (purchase/sale agreement);

- transportation costs;

- other costs directly related to the acquisition and maintenance of the animal for the intended purpose;

- costs of its mandatory registration;

- the cost of training the dog;

- feeding costs;

- costs of treatment and veterinary care (in particular, costs of treatment in case of cruel treatment of an animal with bodily injuries, mutilations);

- costs associated with cremation, disposal of the dead animal (in case of cruelty to animal).

Only in the presence of the above-mentioned initial data a commodity expert can begin the evaluation process.

The stage of pet evaluation involves the division of the process into several stages:

- defining the purpose of the research and the question posed;

${ }^{1}$ Про затвердження Національного стандарту № 1 ... URL: https://zakon.rada. gov.ua/laws/show/1440-2003-п (date accessed: 12.03.2021).

${ }^{2}$ Марчук A. A. Op. cit. URL: https://animal.kharkov.ua/archiv/ntb/STB123/15.pdf (date accessed: 12.03.2021). 
- analysis of documents and information provided for research (case materials);

- substantiation and choice of methodical approaches to evaluation;

- on the basis of the specified initial data and provided information (breeding and veterinary documents, purchase/sale agreement of an animal) concerning commodity objects, carrying out researches and the corresponding calculations;

- coordination of the obtained results and final conclusions about the market price of the animal for the considered period of time.

To determine the market price using the comparative approach, a forensic expert must identify available information on the selling prices (offer) of an object similar to the object of property valuation ( $\mathrm{dog})$ with appropriate adjustment of differences between the object of comparison and the object of evaluation.

The income methodological approach can be used in determining the market price of the object of research, if the forensic expert has information (data) on the actual and / or expected income of the owner of the object of research (from the most efficient use of the object of evaluation, including income from its possible resale), as well as the costs incurred by the owner ${ }^{1}$.

In disputes over the establishment of damages in the case of torture of animals, disagreements often arise as to their value. For dispute parties, the reliability, transparency and objectivity of the information contained in the conclusion which indicates the cost of losses are important. This task is under the power of specialists who are highly qualified, responsible and with extensive experience in evaluation of loss suffered by the animal owner.

Commodity experts of NSC «Hon. Prof. M. S. Bokarius FSI» have extensive experience in estimating the value of pets, so they are able to transparently and objectively calculate the damage caused to animal owners due to death or damage to animals, and justify the results in accordance with current literature and legal requirements.

Conclusions. Animal research is a fairly new area of activity for commodity experts, so many indicators need to be considered when evaluating animals (specially to determine the financial loss caused to the animal owner).

It should be noted that, as of today in Ukraine, the issue of forensic determination of financial loss caused to the animal owner to compensate for damages related to the death or damage to the animal remains open: in the professional and scientific space lacks the necessary material, which causes difficulties in work of experts.

We hope that this set of indicators that can be used to evaluate such value that will be useful for forensic experts, because during the research you need to use special knowledge and well-verified terminology, which contributes to the adoption of legal and reasonable court decisions.

${ }^{1}$ Про затвердження Національного стандарту № 1 ... URL: https://zakon.rada. gov.ua/laws/show/1440-2003-п (date accessed: 12.03.2021). 


\section{References}

Antoniuk, D. O. (2014). Zhorstoke povodzhennia z tvarynamy: poniattia ta oznaky skladu zlochynu. Chetverti kharkivski kryminalno-pravovi chytannia : tezy dop. ta nauk, povidoml. uchasn. Mizhnar. nauk. konf. stud. ta aspirantiv (Kharkiv, 16-17.05.2014). Kharkiv [in Ukrainian].

Holovko, I. A. (2010). Kryminalna vidpovidalnist za zhorstoke povodzhennia z tvarynamy : avtoref. dys. ... kand. yuryd. nauk. Kyiv [in Ukrainian].

Instruktsiia pro pryznachennia ta provedennia sudovykh ekspertyz ta ekspertnykh doslidzhen : zatv. nakazom Min'iustu Ukrainy vid 08.10.1998 r. № 53/5 (zi zmin. ta dopov.). URL: https://zakon.rada.gov.ua/laws/show/z0705-98 (data zvernennia: 18.03.2021) [in Ukrainian].

Kalmykov, D. O., Danylevskyi, A. O. (2013). Kryminalna ta administratyvna vidpovidalnist za zhorstoke povodzhennia z tvarynamy : monohrafiia. Luhansk [in Ukrainian].

Kodeks Ukrainy pro administratyvni pravoporushennia : Zakon Ukrainy vid 07.12.1984 r. № 8073-X (zi zmin. ta dopov.). URL: https://zakon.rada.gov.ua/laws/show/8073110 (data zvernennia: 18.03.2021) [in Ukrainian].

Kryminalnyi kodeks Ukrainy : Zakon Ukrainy vid 05.04.2001 r. № 2341-III (zi zmin. ta dopov.). URL: https://zakon.rada.gov.ua/laws/show/2341-14 (data zvernennia: 18.03.2021) [in Ukrainian].

Marchuk, A. A. (2020). Osoblyvosti ekspertnoi otsinky vartosti domashnikh tvaryn. Naukovo-tekhnichnyi biuleten Instytutu tvarynnytstva NAAN. № 123. URL: https:// animal.kharkov.ua/archiv/ntb/STB123/15.pdf (data zvernennia: 12.03.2021) [in Ukrainian].

Pro sudovu ekspertyzu : Zakon Ukrainy vid 25.02.1994 r. № 4038-KhII (zi zmin. ta dopov.). URL: https://zakon.rada.gov.ua/laws/show/4038-12 (data zvernennia: 18.03.2021) [in Ukrainian].

Pro zakhyst tvaryn vid zhorstokoho povodzhennia : Zakon Ukrainy vid 21.02.2006 r. № 3447-IV (zi zmin. ta dopov.). URL: https://zakon.rada.gov.ua/laws/show/344715 (data zvernennia: 15.03.2021) [in Ukrainian].

Pro zatverdzhennia Natsionalnoho standartu № 1 «Zahalni zasady otsinky maina i mainovykh prav» : Postanova KMU vid 10.09.2003 r. № 1440 (zi zmin. ta dopov.). URL: https://zakon.rada.gov.ua/laws/show/1440-2003-p (data zvernennia: 12.03.2021)[in Ukrainian].

Shevchenko, O. V. (2017). Vykorystannia spetsialnykh tovaroznavchykh znan pid chas dosudovoho rozsliduvannia : dys. ... kand. yuryd. nauk. Kyiv [in Ukrainian].

Tsyvilnyi kodeks Ukrainy : Zakon Ukrainy vid 16.01.2003 r. № 435-IV (zi zmin. ta dopov.). URL: https://zakon.rada.gov.ua/laws/show/435-15 (data zvernennia: 18.03.2021) [in Ukrainian].

Turska, V. O. (2016). Administratyvno-pravove rehuliuvannia zakhystu tvaryn vid zhorstokoho povodzhennia : dys. ... kand. yuryd. nauk. Odesa [in Ukrainian].

Yatsenko, I. V., Derecha, L. M., Parylovskyi, O. I. (2020). Osoblyvosti struktury vysnovku sudovo-veterynarnoho eksperta za rezultatamy doslidzhennia trupa tvaryny z oznakamy nasylnytskoi smerti. Teoriia ta praktyka sudovoi ekspertyzy i kryminalistyky: zb. nauk. pr. Kharkiv. Vyp. 21. S. 615-639. DOI: https://doi. org/10.32353/khnrife.1.2020.44 (data zvernennia: 18.03.2021) [in Ukrainian]. 
Yatsenko, I. V., Zapara, S. I., Zakhar'iev, A. V., Kyrychenko, V. M., Skrypka, M. V., Serdiukov, Ya. K. (2018). Sudovo-ekspertni vypadky doslidzhennia trupiv tvaryn z oznakamy nasylnytskoi smerti vid zhorstokoho povodzhennia. Problemy zooinzhenerii ta veterynarnoi medytsyny: zb. nauk. pr. KhDZVA. Kharkiv. Vyp. 35. Ch. 2. T. 3. $130-138$ [in Ukrainian].

\section{О. В. Мануленко, Т. А. Заніна, А. П. Копитько, Т. М. Чекін Проблемні питання з оцінювання домашніх тварин під час проведення судових товарознавчих експертиз}

У статті розглянуто проблемні питання, щзо виникають під час визначення вартості тварини. Особливо иче стосується випадків, коли необхідно обрахувати матеріальну шкоду, завдану власникові тварини в разі встановлення факту жорстокого поводження з твариною з нанесенням тілесних ушкоджень, спричиненням ї̈ каліитва чи загибелі. Тварина у цььому разі стає об'єктом цивільних правовідносин. Обтрунтування належності живих тварин до категорії "об'єкт ичивільних прав» пов'язане з тим, щзо останні є об'єктами оцінки в матеріальній формі - рухомим майном, споживчим товаром. Отже, оцінка перетворює тварину на особливий об 'єкт цчивільних прав, на який поширюється правовий режим речі.

Під час проведення судових товарознавчих експертиз останнім часом усе більи актуальним стає питання визначення вартості домашніх тварин (зокрема, обрахування матеріального збитку, заподіяного власникові тварини в разі жорстокого поводження із завданням тілесних ушкоджень, спричиненням ї̈ калічтва чи загибелі).

Проблема полягає в тому, що під час проведення такого роду досліджень необхідний повний перелік вихідних даних про об'єкт дослідження, сукупність морфологічних, фізіологічних (зовнішніх, внутрішніх) показників, господарських ознак і властивостей, щчо формують і характеризують тварину як одне иіле. Кожен показник та особливість впливає на таку вартість.

Проведення судових товарознавчих експертиз з очінки домашніх тварин, зокрема, з метою визначення матеріальної шкоди, завданої власникові тварини у разі жорстокого поводження з нею, потребує індивідуального підходу в кожному окремому випадку з урахуванням індивідуальних особливостей та за умови отримання повних вихідних даних для ідентифікації об'єктів дослідження.

У суперечках щцодо встановлення розміру матеріального збитку в разі катування тварин часто виникають розбіжності, щуо стосуються вартості ичих тварин. Для обох сторін суперечки важливі достовірність, прозорість і об 'єктивність інформації, зазначеної в експертизі, яка визначає розмір збитку. Упоратися з таким завданням здатні фахівці з високою відповідальністю та значним досвідом роботи у сфері оцінки збитку, якого зазнав власник тварини. 
Розглядувана сукупність показників, за якими можна визначити таку вартість, стане в пригоді експертам, адже під час проведення дослідження потрібно послуговуватися чіткою термінологію та спеціальними знаннями, щчо сприятиме ухваленню законних і обтрунтованих судових рімень.

Ключові слова: судова товарознавча експертиза, очінка, ринкова вартість, домашні тварини, матеріальна шкода, жорстке поводження з тваринами.

\section{А. В. Мануленко, Т. А. Занина, А. П. Копытько, Т. М. Чекин Проблемные вопросы по оценке домашних животных при проведении судебных товароведческих экспертиз}

В статье рассмотрены проблемные вопросы, возникающие при определении стоимости животного. Особенно это касается случаев, когда необходимо определить материальный ущерб, нанесённый владельиу животного при установлении факта жестокого обращения с животным с нанесением телесных повреждений, увечья или гибели. Животное в данном случае выступает объектом гражданских правоотнотений. Обоснование отнесения живых животных к категории «объект гражданских прав» связано с тем, что последние выступают объектами оценки в материальной форме - движимым имуществом, товаром. Следовательно, оценка превращает животное в особый объект гражданских прав, на который распространяется правовой режсим вещии.

При проведении судебных товароведческих экспертиз в последнее время всё более актуальным становится вопрос определения стоимости домашних животных, в том числе определение материального ущерба, причинённого владельиу животного в случае жестокого обращения с нанесением телесных повреждений, увечья или гибели.

Проблема в том, что при проведении такого рода исследования необходим полный перечень исходных данных об объекте исследования, совокупность показателей, морфологических, физиологических (внешние, внутренние), хозяйственных признаков и свойств, которые формируют и характеризуют животное как одно иелое. Каждый показатель и особенность влияет на стоимость животного.

При назначении и проведении такого рода экспертиз требуется индивидуальньй подход в каждом отдельном случае с учётом особенностей и при условии получения полных исходных данных для идентификации объектов исследования.

В спорах по установлению материального ущерба в случаях истязания животных часто возникают разногласия, касающиеся его стоимости. Для обеих сторон спора важны достоверность, прозрачность и объективность информации, указанной в экспертизе, определяющей размер ущерба. Справиться с такой задачей под силу спечиалистам с высокой ответственностью и с большим опытом работы в сфере оценки ущерба, понесённого собственником животного. 
Рассматриваемая совокупность показателей, по которым можно определить такую стоимость, пригодится экспертам, ведь при проведении исследования нужно применять чётко выверенную терминологию и специальные знания, которые способствуют принятию законных и обоснованных судебных решений.

Ключевые слова: судебная товароведческая экспертиза, оценка, pыночная стоимость, домашние животные, материальный ущерб, жестокое обращение с животными.

Надійшло до редколегії 31.03.2021 p.

Manulenko O., Zanina T., Kopytko A., Cechin T. Problematic issues on the evaluation of domestic animals during forensic commodity expertises. Теорія та практика судової експертизи і криміналістики : зб. наук. пр. / редкол.: О. М. Клюєв, В. Ю. Шепітько та ін. Харків : Право, 2021. Вип. 23. С. 359-371. DOI: https://doi.org/10.32353/ khrife.1.2021.28. 